\title{
Left Ventricle Apical Fibroelastoma: A Rare Finding
}

\author{
Mohsin Khan*, Ijaz Malik, Arshad Jahangir, David Kress and Tanvir Bajwa \\ Center for Advanced Atrial Fibrillation Therapies, Advocate Aurora Cardiovascular Services, Advocate Aurora Health, USA.
}

*Corresponding author: Arshad Jahangir, Director Center for Advanced Atrial Fibrillation Therapies, Associate Director Clinical Cardiac Electrophysiology Fellowship Program, Aurora Cardiovascular and Thoracic Services, Advocate Aurora Health, 2801 W. Kinnickinnic River Parkway, \#880, Milwaukee, WI 53215.

To Cite This Article: Mohsin Khan, Ijaz Malik, Arshad Jahangir, David Kress, Tanvir Bajwa. Left Ventricle Apical Fibroelastoma: A Rare Finding. 2020 - 9(4). AJBSR.MS.ID.001419. DOI: 10.34297/AJBSR.2020.09.001419.

Received: 䟧April 28, 2020; Published: 眥 July 15, 2020

\begin{abstract}
Introduction
Primary cardiac tumors are rare and are reported with a frequency of $0.02-0.1 \%$ in autopsy series [1]. Fibroelastoma is the third most common benign neoplasm of the heart after myxoma and lipoma, accounting for $<10 \%$ of all cardiac tumors [2]. They may be asymptomatic or can present as potential source of embolism to different parts of the body. Fibroelastoma arising from left ventricle (LV) apex is an extremely rare entity. Only 11 cases have been reported about fibroelastoma arising from LV apex in the MEDLINE database [3-11]. Here we describe a case of fibroelastoma arising from LV apex that presented with retinal artery occlusion.
\end{abstract}

Keywords: Fibroelastoma; Embolism; Left ventricle apex; Stroke; Retinal; Cardiac tumor

\section{Case Report}

A 75-year-old female presented with a two-week history of visual loss involving the right eye. She saw an ophthalmologist who diagnosed her with right retinal artery occlusion. She was admitted to the hospital for further evaluation and treatment. Her past medical history includes diabetes mellitus type II, bilateral carotid artery stenosis, peripheral arterial disease s/p stenting of left superficial femoral artery, bilateral renal artery stenosis $s / p$ stenting, chronic kidney disease (CKD) stage III and hypertension. She continues to smoke a pack a day for the last 50 years. Her medications include aspirin, clopidogrel, lisinopril, simvastatin and triamterene-hydrochlorothiazide. On admission, physical examination, EKG and laboratory findings were unremarkable. Transthoracic echocardiography revealed a mobile well delineated homogeneous echogenic mass measuring approximately $1 \mathrm{~cm}$ within the LV attached to the apex by a stalk (Figures1A,1B).
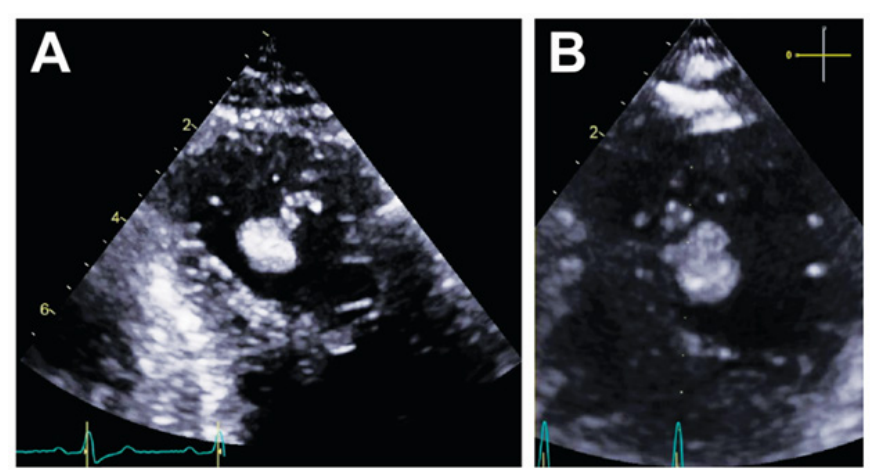

Figure 1A,1B: (A) Left ventricle apical view demonstrating cardiac mass, and (B) shows the cardiac mass in the apical short axis view. 
The patient was started on a heparin drip. Cardiac catheterization showed multivessel coronary artery disease. She underwent myocardial revascularization with a saphenous vein graft to RCA and OM1 and the LV mass was removed via left atrial atriotomy and transmitral approach. The mass was $0.7 \times 0.5 \times 0.4 \mathrm{~cm}$ in size, ovoid and white rubbery in appearance (Figure 2). Pathology revealed acellular eosinophilic fibrous tissue with a papillary surface architecture, findings consistent with fibroelastoma (Figure 3A,3B). Her postoperative course was uncomplicated, and she was discharged home 7 days after her surgery and has done well on follow-up.

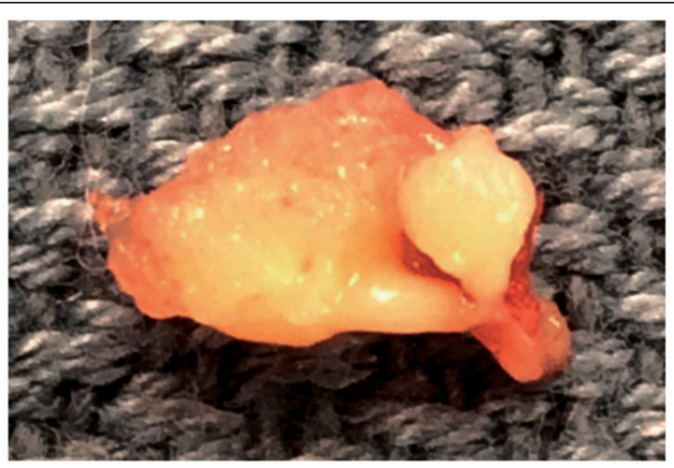

Figure 2: Cardiac mass with pearly white gelatinous membrane and multiple papilary projections consistent with fibroelastoma.
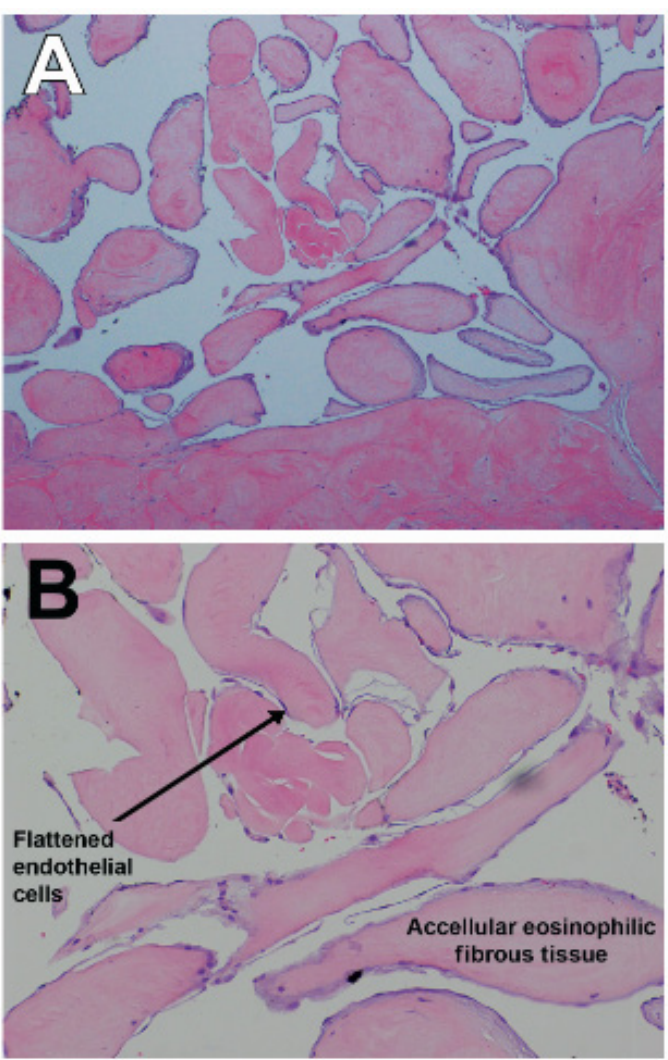

Figure 3A,3B: (A)Micrograph with hematoxylin-and-eosin staining $(\times 40)$ showing multiple avascular papillary fronds. The stroma is fibroelastic with prominent myxoid changes. (B) H\& E stain (x100) showing flattened endothelial cells.

\section{Discussion}

Fibroelastomas account for $<10 \%$ of all cardiac tumors and are the most common tumor arising from the valves with rare reports of origin from the LV. The majority (77-90\%) of fibroelastoma arise from the valvular endocardium $[12,13]$. The aortic valve $(29 \%)$ is most commonly involved followed by the mitral valve $(25 \%)$ and tricuspid valve (17\%). A review of the literature was performed for the cases of fibroelastoma arising from the LV apex with findings shown in Table 1. Out of 11 cases, eight were female (72\%) with average age of 68 years at the time of diagnosis. The presentation 
ranged from incidental finding on transthoracic echocardiogram done for other reasons (four patients) to transient ischemic attack (TIA)/stroke in three patients. None of the tumors were greater than $2 \mathrm{~cm}$ in dimension. Fibroelastoma is characteristically described as a small, friable mass with multiple fronds like a sea anemone with dense fibroelastic cores and endocardial linings [14]. The papillary fronds contain fibrous tissue, elastic fibers and smooth muscle cells in a mucopolysaccharide matrix covered with hyperplastic endocardial cells. Fibroelastoma can be asymptomatic and discovered incidentally on imaging or present with life-

Table 1: Characteristic of patients with LV apical fibroelastoma.

\begin{tabular}{|c|c|c|c|c|c|}
\hline Age ( yrs) & Sex & Presentation & Imaging & Tumor size (cm) & Surgical approach \\
\hline 75 & $\mathrm{~F}$ & Incidental & Transesophageal echocardiogram & $1.5 \times 1.2$ & $\begin{array}{l}\text { Right thoractomy approach ,Left atrial } \\
\text { atriotomy }\end{array}$ \\
\hline 81 & $\mathrm{~F}$ & Incidental & Transthoracic echo & 1.3 & $\begin{array}{l}\text { Midline sternotomy approach, Left } \\
\text { atrial atriotomy }\end{array}$ \\
\hline 75 & $\mathrm{~F}$ & Incidental & Transthoracic echo & No info & $\begin{array}{l}\text { Right thoractomy approach, Left atrial } \\
\text { atriotomy }\end{array}$ \\
\hline 81 & $\mathrm{~F}$ & palpitations & Transthoracic echo & 1.5 & $\begin{array}{l}\text { Midline sternotomy approach, Left } \\
\text { atrial atriotomy }\end{array}$ \\
\hline 59 & $\mathrm{~F}$ & stroke & Transesophageal echo & 1.1 & $\begin{array}{l}\text { Midline sternotomy approach, Left } \\
\text { ventriculotomy }\end{array}$ \\
\hline 74 & $\mathrm{~F}$ & Incidental & Transthoracic echo & $1.9 \times 1.5$ & $\begin{array}{l}\text { Midline sternotomy approach, Left } \\
\text { atrial atriotomy }\end{array}$ \\
\hline 46 & $\mathrm{~F}$ & Nonspecific fevers & Transthoracic echo & $1.4 \times 1.7$ & $\begin{array}{l}\text { Midline sternotomy approach, Left } \\
\text { ventriculotomy }\end{array}$ \\
\hline 55 & M & Transient ischemic attack & Transthoracic echo & $2 \times 1.5$ & $\begin{array}{l}\text { Midline sternotomy approach, Left } \\
\text { ventriculotomy }\end{array}$ \\
\hline 68 & M & TIA & Transthoracic echo & $1.6 \times 1.1$ & $\begin{array}{l}\text { Midline sternotomy approach, } \\
\text { aortotomy }\end{array}$ \\
\hline 67 & $\mathrm{~F}$ & Exertional dyspnea & Transthoracic echo & $2 \times 1.5$ & $\begin{array}{l}\text { Midline sternotomy approach, Left } \\
\text { ventriculotomy }\end{array}$ \\
\hline 69 & M & Atrial fibrillation & Transthoracic echo & 1.4 & $\begin{array}{l}\text { Midline sternotomy approach, Left } \\
\text { atrial atriotomy }\end{array}$ \\
\hline
\end{tabular}

\section{Reference}

1. Reynen K (1996) Frequency of primary tumors of the heart. Am J Cardiol 77(1): 107.

2. Edwards FH, Hale D, Cohen A, Thompson L, Pezzella AT, et al. (1991) Primary cardiac valve tumors. Ann Thorac Surg 52(5): 1127-1131.

3. Kaneko Y, Kobayashi J, Saitoh F, Ono M (2006) Thoracoscopic removal of a papillary fibroelastoma in the left ventricular apex. Interact Cardiovasc Thorac Surg 5(5): 640-642.

4. Goel M, Malhotra R, Kohli V, Mishra M, Jain S, et al. (2003) Left ventricular fibroma causing atypical chest pain. Asian Cardiovasc Thorac Ann 11(3): 258-260.

5. Tkebuchava T, von Segesser LK, Gallino A, Dirsch O, Turina MI (1997) Cardiac papillary fibroelastoma excision combined with reconstructive surgery. Jpn Heart J 38(3): 457-462.

6. Veinot JP, O’Murchu B, Tazelaar HD, Orszulak TA, Seward JB (1996) Cardiac fibroma mimicking apical hypertrophic cardiomyopathy: a case report and differential diagnosis. J Am Soc Echocardiogr 9(1): 94-99.

7. Company Campins MM, Antón E, Enríquez F, Palmer J, Serra JE, et al. (2007) Cardiac papillary fibroelastoma in left ventricular apex. Cardiovasc Pathol 16(5): 317-319. threatening complications secondary to embolization [15]. There is significant association between clinically diagnosed fibroelastoma and neurological events. The risk of cerebrovascular event is high, ( $6 \%$ at 1 year and $13 \%$ at 5 years) [16]. Papillary fibroelastomas can also result in angina [17], myocardial infarction, or even sudden death through direct occlusion of the coronary arteries [18] or embolization to a coronary vessel or peripheral embolization [19]. Syncope can result if the mass is large enough to block LV outflow tract [20]. Given the high risk of embolization, surgical resection is recommended [12,19] (Table 1). 
15. Klarich KW, Enriquez Sarano M, Gura GM, Edwards WD, Tajik AJ, et al. (1997) Papillary fibroelastoma: echocardiographic characteristics for diagnosis and pathologic correlation. J Am Coll Cardiol 30(3): 784-790.

16. Tamin SS, Maleszewski JJ, Scott CG, Khan SK, Edwards WD, et al (2015) Prognostic and Bioepidemiologic Implications of Papillary Fibroelastomas. J Am Coll Cardiol 65(22): 2420-2429.

17. Wickendon J, Khan H, Chaubey S, Butt S, Desai J (2016) Papillary Fibroelastoma Causing Left Ventricular Outflow Obstruction and Systolic Anterior Motion (SAM). J Card Surg 31(5): 330-331.

18. Ikegami H, Andrei AC, Li Z, McCarthy PM, Malaisrie SC (2015) Papillary fibroelastoma of the aortic valve: analysis of 21 cases, including a presentation with cardiac arrest. Tex Heart Inst J 42(2): 131-135.
19. Abu Saleh WK, Al Jabbari O, Ramlawi B, Reardon MJ (2016) Cardiac Papillary Fibroelastoma: Single-Institution Experience with 14 Surgical Patients. Tex Heart Inst J 43(2): 148-151.

20. Khoueiry G, Geha F, Meghani M, Abi Rafeh N, Azab B, et al. (2013) An unusual case of giant cardiac fibroelastoma mimicking left atrial myxoma in a patient presenting with syncope. J Clin Ultrasound 41(3): 191-194. 